\title{
SZÜLŐI SEGÍTSÉGNYÚJTÁS A JELENLÉTI ÉS TÁVOLLÉTI OKTATÁS IDEJÉN
}

\author{
ENGLER ÁGNES ${ }^{a, b, *}$ - MARKOS VALÉRIA ${ }^{b}$ - DUSA ÁGNES RÉKA \\ ${ }^{a}$ Debreceni Egyetem Bölcsészettudományi Kar \\ Nevelés- és Müvelődéstudományi Intézet \\ ${ }^{b}$ Kopp Mária Intézet a Népesedésért és a Családokért
}

Beérkezett: 2020. december 14., elfogadva: 2021. január 16.

Tanulmányunk fókuszában a koronavírus során bevezetett járványügyi intézkedések gyermekeket érintő kérdései állnak, a járványnak a családok időgazdálkodásra való hatása és az otthoni tanulás, digitális átállás nehézségei. Kutatásunkban egy telefonos kérdőíves lekérdezésen (CATI) alapuló adatbázist használunk, melyet a járvány első hulláma idején készítettek, 2020 áprilisában a Kopp Mária Intézet megbízásából $(N=1000)$. Vizsgáljuk, hogy mi befolyásolja az otthoni tanulást akkor, ha a szülőknek esetleg a tananyag elsajátításában is segítséget kell nyújtaniuk. Eredményeink szerint a családok többségének lehetősége és szándéka volt a közös tanulásra, ennek mértékére és mikéntjére nem a megszokott társadalmi háttérváltozók mentén találtunk különbségeket, hanem a családi kapcsolatok és az otthoni munkavégzés kapcsán.

Kulcsszavakः digitális oktatás, otthoni tanulás, járványhelyzet

The focus of our study is on the issues of epidemiological measures introduced during the coronavirus that affect children, the impact of the pandemic on time management of families and the difficulties of home learning and digital transition. In our research, we use a database based on a telephone questionnaire (CATI), which was created during the first wave of the pandemic, in April 2020 on behalf of the Mária Kopp Institute $(N=1000)$. We examine what influences home learning when parents may need to help with curriculum acquisition. According to our results, the majority of families had the opportunity and intention to learn together, and we did not find differences in the extent and manner of this along the usual social background variables, but in relation to family relationships and working from home.

Keywords: digital education, home learning, pandemic situation

* Levelező szerző: Engler Ágnes, Debreceni Egyetem Nevelés- és Művelődéstudományi Intézet, 4032 Debrecen, Egyetem tér 1. E-mail: engler.agnes@koppmariaintezet.hu 


\section{Bevezetés}

A tanulók iskolai teljesítményében és magatartásában a családi háttérnek vitathatatlan a szerepe. A szakmai életút elejének számító közoktatás éveiben a családi erőforrások, a családtagok által birtokolt tőkefajták jelentősen befolyásolják a gyermekek és fiatalok előrehaladását, a társadalmi egyenlőtlenségek pedig kevésbé látszanak kiegyenlítődni az iskolarendszerben (ld. pl. Bourdieu 1978; Coleman 1974; Boudon 1998; DiMaggio 1998; Kozma 1999; Róbert 2001; Pusztai 2005; Róbert 2004; Szemerszki 2015). A kulturális reprodukció (Bourdieu 1978) az eltérő társadalmi helyzetből származó oktatási egyenlőtlenségekre ad magyarázatot: az iskola által jutalmazott viselkedési formák, a nyelvi és kommunikációs készségek és a kultúrához való viszony a szülők kulturális tőkéjéből fakadnak, amelynek nagysága eltér a különböző társadalmi osztályokba tartozó családoknál. Azok a szülők pedig, akik gyermekeiket magasabb iskolázottságra, az övékétől magasabb pozíció elérésére ösztönzik, nagyobb figyelmet fordítanak az otthoni felkészülésükre (ld. pl. Sheldon-Epstein 2005; SirajBlatchford 2010; Ceglédi 2018).

Újabb kutatások sora igyekszik azonban rámutatni arra, hogy a család hatása a gyermekek teljesítményére nemcsak a szocioökonómiai státus függvényében elemezhető. A család szerkezete, a családtagok között lévő viszony, a család légköre, a családban folytatott kommunikáció, a gyermekre fordított minőségi idő nemcsak a teljesítményt és iskolai pályafutást befolyásolja, hanem hatással van a gyermek testi-lelki fejlődésére is (Buda 1998; Kelley-Sequeira 1997; Volling-Notaro-Larsen 1998; Kopp-Skrabski 2000; Croll 2004; Brown 2006; Vandeleur et al. 2009; Pusztai 2020). A társadalmi háttérből fakadó hátrányok tehát tompíthatók, csökkenthetők, s ebben nagy szerepet játszik a család és az iskola rendszeres kommunikációja is. Epstein és munkatársai szerint a szülők ideje, érdeklődése, elkötelezettsége, életkörülményei határozzák meg az iskola és a család kapcsolatát, kommunikációját. Hat különböző típusba sorolja a szülői részvétel megvalósulását, a passzív és aktív végpontok között számos variációval. Az egyik típusban megjelenik a napi rendszerességgel végzett közös tanulás (Epstein-Galindo-Sheldon 2013).

A szülők iskolai életbe történő bekapcsolódásának, más szóval bevonódásának ugyanis egyik fontos szegmense az otthoni tanulás. Ebbe a fogalomkörbe egyrészt a ténylegesen a tanulásra szánt idő tartozik bele, például a házi feladat ellenőrzése, az abban való segítségnyújtás, a lecke szóbeli kikérdezése, a felszerelés ellenőrzése. Ezenfelül Papp-Danka (2014) tanulási környezetet is érintő munkája alapján, a jelenléti oktatás esetén is szerves részhez jut a digitális világ az otthoni tanulásban.

A szülők az otthoni tanuláshoz formális, módszertani segítséget általában nem kapnak, leginkább saját tapasztalatukat „viszik bele” a segítségnyújtásba. Oostdam és Hooge (2013) utal rá, hogy a pedagógusok vagy megfelelő információval és módszerekkel látják el a szülőket az otthoni felkészülés területén, vagy egyszerűen biztonságos távolságban tartják őket. Markos (2020) a tanórán kívüli tevékenységben, különösen az iskolában megvalósuló korrepetáló és fejlesztő foglalkozások során fedezett fel olyan pedagógiai segítségnyújtást, amely akár hátránykompenzáló is lehet az iskolai pályafutásban, segítve (vagy mentesítve) a szülők otthoni segítségnyújtását.

$\mathrm{A} z$ iskolai munkával kapcsolatos szülői magatartás része az iskolában történt események kikérdezése, megbeszélése, amely már nemcsak az órai történésekre, hanem például 
a közösségi beilleszkedésre is vonatkozik. A szülők otthoni tevékenységük során elsősorban a szerzett jegyekről és a házi feladatról érdeklődnek, de kérdeznek a barátokról, osztálytársakról is. Kimutatható, hogy a nem szorosan az iskolai teljesítményhez kötődő beszélgetések, az otthoni kommunikáció gyakorisága is rendkívül jó hatással van magára az iskolai eredményességre (Imre 2015). Amennyiben a család és az iskola nevelési céljai és értékei összehangban vannak, a köztük lévő együttmüködés és ezáltal az eredményesség is nagyobb eséllyel éri el a kívánt mértéket. Egy később érintőlegesen bemutatott hazai vizsgálat adatai szerint a magyar szülők nevelési értékei legtöbb esetben harmonizálnak az általuk választott iskola pedagógiai értékeivel és céljaival (Dusa 2020).

A nevelési célok otthoni megvalósulásában az együtt töltött idő kap jelentőséget. Bár számos kutatás arra hívja fel a figyelmet, hogy az indusztriális társadalmakban csökkent a szülőknek a gyermekeikkel közösen eltöltött ideje (ld. Gautbier-Smeeding-Furstenberg 2004), a magyar eredmények azt mutatják, hogy a gyermekes családok körében a közös tevékenységekre fordított idő mértéke nem csökkent (Harcsa 2014).

Az anya és a gyermek közös időtöltését számos demográfiai tényező is befolyásolja. Egyes kutatások azt igazolják, hogy az anya iskolai végzettsége pozitív összefüggést mutat a gyermekkel való kapcsolattal, valamint az interakciók minőségével és mennyiségével a magasabb végzettségüek javára (Bloemen-Stancanelli 2008; Engler 2011). Craig és munkatársai szerint az anyák iskolázottságából fakadó különbségek eltüntek, s inkább a foglalkoztatottság hatása erősödött: különösen a gyermekkel való beszélgetésben mutatkozott meg a nem dolgozó anyák „előnye” (Craig-Powell-Smyth 2014). További kutatások is azt bizonyítják (Connelly-Kimmel 2007; Kalenkoski-Ribar-Stratton 2008; TürkoğluUslu 2019), hogy a dolgozó anyák kevesebb időt fordítanak a gyermekkel közös minőségi időtöltésre, mint a nem dolgozó anyák. Ennek ellentmondanak Zick és munkatársainak eredményei, miszerint a munkavállaló anyák több időt töltenek a gyermekkel olyan speciális tevékenységekkel, mint a könyvolvasás és a házi feladatok elkészítése (Zick-BryantÖsterbacka 2001).

A koronavírus-járvány első hullámának idején bevezetett távolléti oktatás új keretet adott az otthoni tanulásnak. Míg a járvány előtt meghatározott időkeretben (jellemzően késő délutáni és esti órák) és megszokott módon (házi feladat elkészítése, tanultak memorizálása, gyakorlás) merült ki a tevékenység, egy viszonylag szük körben (szülői segítség, esetleg magántanár), addig a digitális oktatásban az otthoni tanulás egésznapossá vált, a fentieken kívül magában foglalta az új anyag elsajátítását és a mérésértékelést is. Egyúttal bővült a bevonódók köre: a szülőkön kívül a nagyobb testvérek, rokonok is segítettek, de aktív osztálytársi együttmüködés is kialakult, valamint egyes programok (pl. Tanítsunk Magyarországért) vagy az egyetemi tanárképzés keretében hallgatói tutorok is közremüködtek.

A koronavírus okozta tavaszi karantén és otthontanulás idején készült első vizsgálatok szerint a granovetteri definíció szerinti gyenge és erős kötelékek egyaránt képesek voltak segíteni az egyéneket a kényszerhelyzet alatt - igaz, ez elsősorban valószínüleg azokra igaz, akiknél eleve jók voltak a családi kapcsolatok, míg a rejtett konfliktusokat előhozhatta a karantén (Mihályi 2020). A nagyobb szülői leterheltség elsősorban az alsós gyereket nevelők esetében jelentkezett, s közöttük is az alacsonyabb digitális kompetenciájú szülőknek okozott problémát (Proháczik 2020). Thékes (2020) a digitális átállás első szakaszában készült Békés megyei kutatása szerint a válaszadók fele valamennyire, harmada eléggé negatívan élte meg a változást. 
Osváth és Papp (2020) vizsgálata szerint a pedagógusok és szülők közötti kapcsolat virtuálissá válása a hirtelen jött karantén miatt kissé nehezen indult meg, de mivel rendelkezésre álltak eszközök és online felületek, így idővel sikerült működőképes kommunikációs csatornákat kialakítani. Bencéné (2020) kutatása ugyanakkor rámutatott arra, hogy a szülők számára a nagyobb arányú (valós idejű) online óratartás lett volna segítség a tananyag elsajátításában, ez azonban kevés tárgy esetén valósult meg rendszeresen. Vizsgálatok sora igyekszik feltárni a leendő pedagógusok digitális oktatásra történő felkészítésének lehetőségeit, illetve a tanárjelöltek képzésének megújítását (ld. pl. Molnár 2020; Kéri 2020; Serfözö et al. 2020; Szüts 2020; Di Pietro et al. 2020; Shivangi 2020; Shahzad-Hassan-Aremu 2020; stb.).

A továbbiakban két idei országos kutatást hívunk segítségül annak érdekében, hogy az otthoni tanulás megvalósulását két különböző oktatási helyzetben figyeljük meg. Az első vizsgálat 2020 első hónapjában zajlott, a járványt megelőzően, jelenléti oktatás idején. A kutatás széles körű témaköreiből csupán a szülői segítségnyújtásra térünk ki, tesszük ezt részletes vizsgálat és hipotézis felállítása nélkül, mintegy előkészítéseként a második, bővebben elemzett kutatásnak. Ez utóbbi adatfelvétele a járvány első hullámában, 2020 áprilisában valósult meg, elsősorban az akkori intézkedések hatékonyságára fókuszálva. Tanulmányunkban a digitális oktatásra történő áttérés eredményességét és nehézségeit vizsgáljuk meg.

\section{Nevelés és oktatás a családokban hagyományos körülmények között}

A z „Értékteremtő gyermeknevelés” (Kopp Mária Intézet a Népesedésért és a Családokért felmérése) 2020 januárjában negyedik osztályos gyermekek szüleit $(N=1156)$ és pedagógusait $(N=144)$ kereste meg. Az adatfelvétel papíralapú, önkitöltős kérdőívvel,

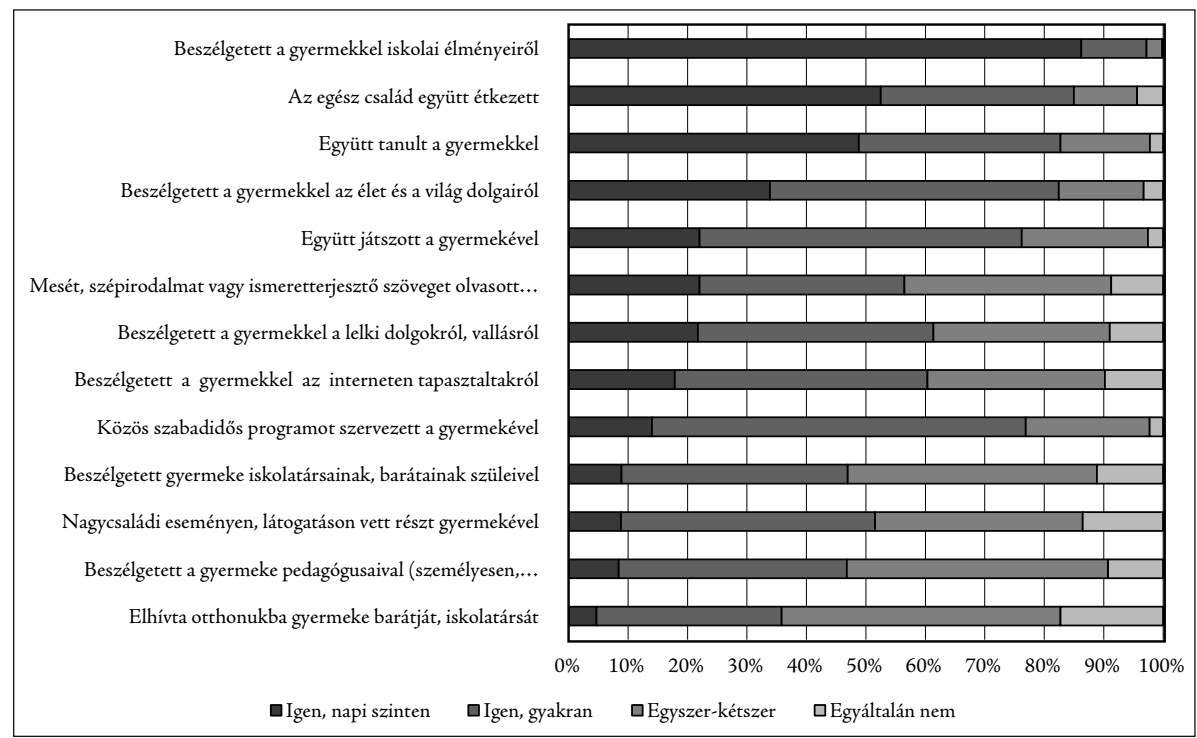

1. ábra: A gyermekkel közösen végzett tevékenységek gyakorisága, százalék Forrás: Értékteremtő gyermeknevelés KINCS kutatás, 2020 
a mintaválasztás többlépcsős, csoportos mintavétellel történt. A válaszadók összetétele regionalitás, lakóhely településtípusa, szociális helyzete szerint reprezentálja a negyedik évfolyamos tanulói populációt. Jelen tanulmányban csupán néhány eredményre hívjuk fel a figyelmet a továbbiak (ti. karanténhelyzetben felvett adatok elemzése) előkészítése és alátámasztása érdekében. ${ }^{1}$

A szülők elmondása szerint a gyermekük egy átlagos hétvégén 2,7 órát tölt szabad (nem online) játékkal, 2,1 órát mobiltelefon vagy tablet társaságában. Harmadik helyen áll az önálló tanulás, átlagban 2 órával, megelőzve minden más szabadidős tevékenységet. A lecke otthoni elsajátítása és begyakorlása nemcsak önállóan történik. A szülö és a gyermek közös tevékenységének gyakorisági rangsorában az együttes tanulás a harmadik helyen áll, megelőzve a közös játékot, olvasást, programokat (1. ábra). A szülők fele naponta, további harmada igen gyakran ül le a gyermeke házi feladata, tanulnivalója mellé. Kiemelendő, hogy a legyakoribb tevékenységnek az iskolai eseményekről való beszélgetés bizonyult, amely valószínüsíthetően tanulmányokkal, órai történésekkel kapcsolatos témákat is felölel.

Úgy tűnik, a szülők a beszélgetésre szánt időt az összes többi tevékenységhez képest elegendőnek tartják, hiszen ez került az elégedettségi rangsor elejére; jegyezzük meg ugyanakkor, hogy a kívánt maximumtól (4-es érték) igen elmarad az átlagérték $(3,07)$ (2. ábra). A közös tanulás a negyedik helyen áll, megelőzve a közös játékot vagy a házimunkát. Megfigyelhető ugyanakkor az is, hogy a gyermekkel és az otthonnal kapcsolatos teendők a lista legelején sorakoznak, maguk mögé sorolva a személyes testi-lelki törődést, mint a saját egészségmegőrzést, kikapcsolódást, feltöltődést.

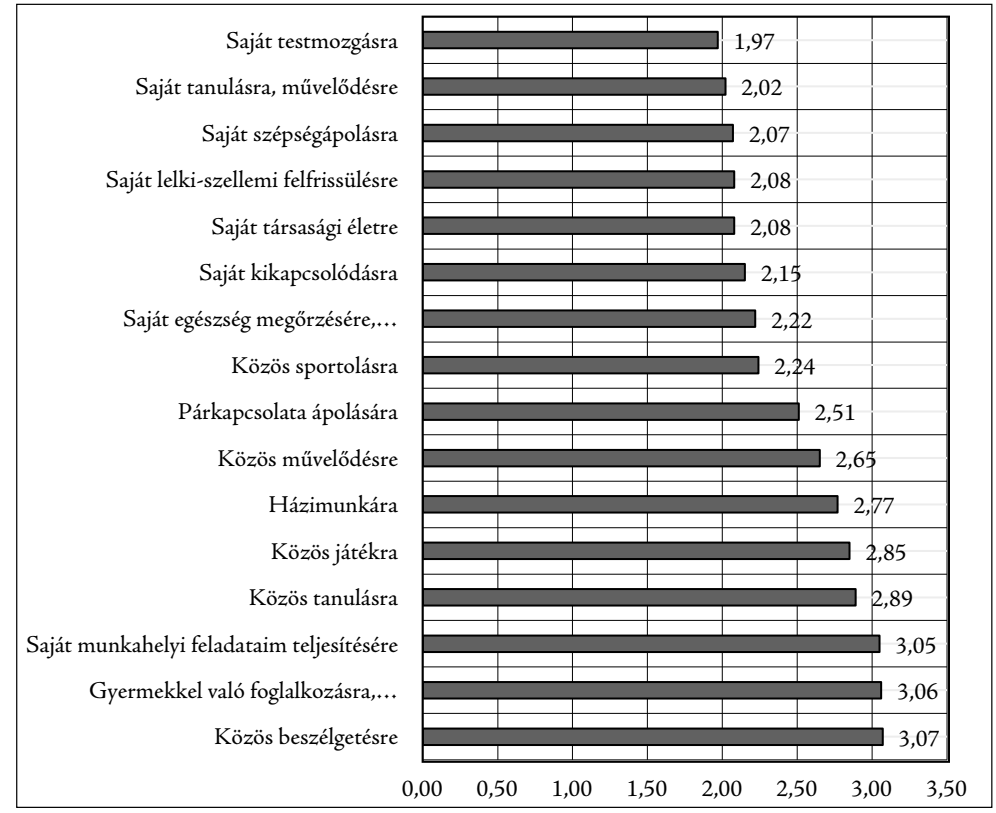

2. ábra: Az időgazdálkodással való elégedettség (négyfokú skála átlagai)

Forrás: Értékteremtő gyermeknevelés KINCS kutatás, 2020

1 A kutatásról és az eredményekről ld. bővebben: Pusztai-Engler 2020. 
Hétvégi szabadidős tevékenységek biztosításában

Képességfejlesztő, tehetséggondozó foglalkozások költségeinek biztosításában

Gyermek elkísérésében a fenti foglalkozásokra

Szabadidős tevékenységek költségeinek biztosításában

Gyermekneveléssel kapcsolatos ismeretem bővitésében

Gyermekneveléssel kapcsolatos tapasztalatokat szülőtársakkal való megosztásához

Szabadidős tevékenységek biztosításában a tanítási szünetekben

Szabadidős tevékenységek biztosításában a tanév közbeni hétköznapokon

Otthoni tanulásban, a házifeladat ellenőrzésében, gyakorlásban

Gyermeke biztonságos és értelmes médiahasználatának biztosításához

Pedagógusokkal gyakrabban megbeszélhesse a gyerekekkel kapcsolatos tapasztalatokat

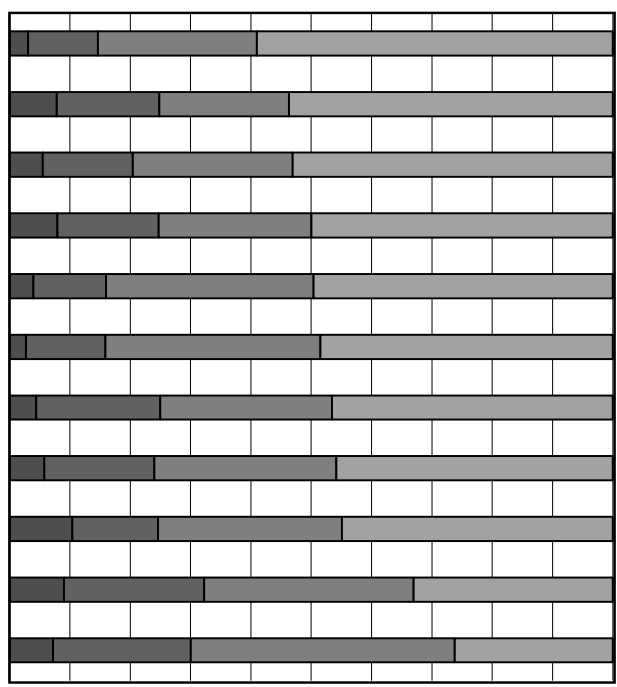

$\begin{array}{lllllllllll}0 \% & 10 \% & 20 \% & 30 \% & 40 \% & 50 \% & 60 \% & 70 \% & 80 \% & 90 \% & 100 \%\end{array}$

口Folyamatosan szükséges lenne

口Gyakran szükséges lenne

$\square$ Ritkán szükséges

$\square$ Szükségtelen

3. ábra: A gyermeknevelés hétköznapi teendőihez szükséges támogatási igények a szülők részéről (\%) Forrás: Értékteremtő gyermeknevelés KINCS kutatás, 2020

A szülők mégsem a személyes jóllétüket érintő területeken igényelnek változást, segítséget, hanem a gyermekükkel kapcsolatos tevékenységekben, kiemelten az iskolai élethez kapcsolódva. A 3. ábrán látható, hogy a kérdőívben felkínált, a gyermeknevelés hétköznapi teendőihez szükséges támogatási formák közül leginkább a pedagógusokkal való kommunikáció gyarapítását és a médiahasználattal kapcsolatos segítséget fogadnák el. Vizsgálatunk szempontjából fontos eredmény, hogy a harmadik helyen megjelenik az otthoni tanulásban nyújtott segítség igénye. Ez valószínüsíthetően tartalmi tudás és módszertani kompetenciák fejlesztését célozza meg.

A jelenléti oktatás idejében készült vizsgálat kiragadott eredményei alapján elmondható, hogy a negyedik osztályos tanulók szülei komoly odafigyelést biztosítanak gyermekük tanulmányi előmenetelére. Rendszeresen leülnek melléjük tanulni, s elvárják tőlük az önálló tanulást is. Valószínúleg a gyakori közös tanulás tapasztalatai nyomán merül fel bennük az igény tudásuk bővítésére, a tudásátadás módszertanának fejlesztésére. A minőség mellett a mennyiséggel, azaz a közös tanulásra fordított idővel sem maradéktalanul elégedettek (négyes skálán 2,9). A tanulmányok mellett a családi beszélgetésekben az iskolai történések is komoly szerephez jutnak. A megkérdezett szülők mindemellett igyekeznek minél több közös időt tölteni gyermekükkel (játék, olvasás, sport, szabadidős programok), az egyéni feltöltődést szolgáló időtöltés a legkevésbé jellemző mindennapjaikban.

\section{Tanulás az iskolává alakuló otthonokban}

Az előzőekben megfigyelhettük, hogy az iskolai oktatást kiegészítő otthoni tanulás is komoly erőfeszítést és kihívást jelent a szülőknek, amelynek igyekeznek a lehető legjob- 
ban megfelelni. A továbbiakban, a tanulmány központi részében megvizsgáljuk, mi történik, ha az otthonok iskolákká alakulnak, s már nem csak segítő, közreműködő szerep jut a szülőknek és családtagoknak.

A Kopp Mária Intézet a Népesedésért és a Családokért (KINCS) „A koronavírus családokra gyakorolt hatása" kutatása 2020 áprilisában zajlott. A vizsgálat telefonos lekérdezéssel történt, összesen 1000 fö 18 évesen felüli magyar állampolgárt kérdeztek meg. A minta nemre, életkorra, iskolai végzettségre és településtípusra reprezentatív volt. A kutatás elsődleges célja annak megvizsgálása, miként reagálnak a családok a járványhelyzetre, melyek azok a kérdések, amelyek leginkább foglalkoztatják őket, mennyire tartják be az óvintézkedéseket, milyen elvárásaik vannak, hogyan alakult az otthoni munkavégzés és a tanulás.

A kutatás tehát elsősorban nem a távolléti oktatás feltérképezését célozta meg, azonban több olyan kérdést is tartalmazott, melyek segítéségével megismerhetjük a járványhelyzet alatti otthoni tanulás jellemzőit, illetve megvizsgálhatjuk, mely tényezők befolyásolják a szülők gyermekkel való tanulását.

Mivel a kutatásban részt vevők 25,8\%-ának, azaz 259 fónek van 18 év alatti gyermeke, így mintánkat leszűkítettük kizárólag ezen csoportra.

\section{Hipotéziseink a következök:}

H1. A szülők iskolai végzettsége befolyásolja a tanulókkal való otthoni tanulást: a tőkeelméleteknek megfelelően feltételezzük, hogy az iskolázottság csökkenésével mérséklődik az együtt tanulás.

H2. A család közös időtöltése és az együtt tanulás között összefüggés mutatható ki: minél több időt tölt a gyermek a családtagjaival, annál jellemzőbb lesz az otthoni közös tanulás.

A következőkben azoknak a társadalmi és egyéb tényezőknek az általános elemzésére és a képzett változók bemutatására vállalkozunk, melyek összefüggésében vizsgáljuk a továbbiakban a karantén alatti szülő és gyermek közös tanulásának megvalósulását.

A válaszadó szülők 57,5\%-a nő és 42,5\%-a férfi. A szülők többsége községben (34,7\%) és egyéb városban (29\%) él, kevesebben megyeszékhelyen (19,7\%) és a fővárosban (16,6\%). A válaszadók többsége diplomával vagy tudományos fokozattal (34\%) és érettségivel rendelkezik (25,9\%), kevesebben szakmunkásképző, szakiskolai végzettséggel (17,8\%), míg legkevesebben nyolc általános vagy annál kevesebb $(12,4 \%)$, vagy középiskola utáni nem felsőfokú végzettséggel (10\%).

A válaszadók 40,2\%-ának két gyermeke van, 30,5\%-ának egy gyermeke, 20,5\%-ának három gyermeke, $5 \%$-ának négy és 3,9\%-ának négynél is több gyermeke van. Az iskoláskorú gyermekek átlagéletkora 11,83 év.

A válaszadó munkaerőpiaci helyzetét a járványhelyzet alatti munkavégzés jellegével vizsgáltuk, a válaszadók 49\%-a teljes munkaidőben, 8,5\%-a részmunkaidőben dolgozott. A válaszadók 9,3\%-a távmunkában dolgozott a kérdezés idején.

A családok anyagi helyzetét egy összevont mutatóval mértük, mely tartalmazta a válaszadó szubjektív anyagi helyzettel való elégedettségét, hiteltartozását és a megtakarítását. Általánosságban elmondható, hogy a válaszadók 64,6\%-a beosztással jól kijön vagy gondok nélkül él, 61,9\%-ának van hitele vagy tartozása, azonban 55,8\%-ának 
megtakarítása is van. E változók dummy változóvá alakítását követően az index létrehozásakor egy 0-3-ig terjedő skálát kaptunk. Ezen a skálán a válaszadók átlagosan 1,58 pontot értek el.

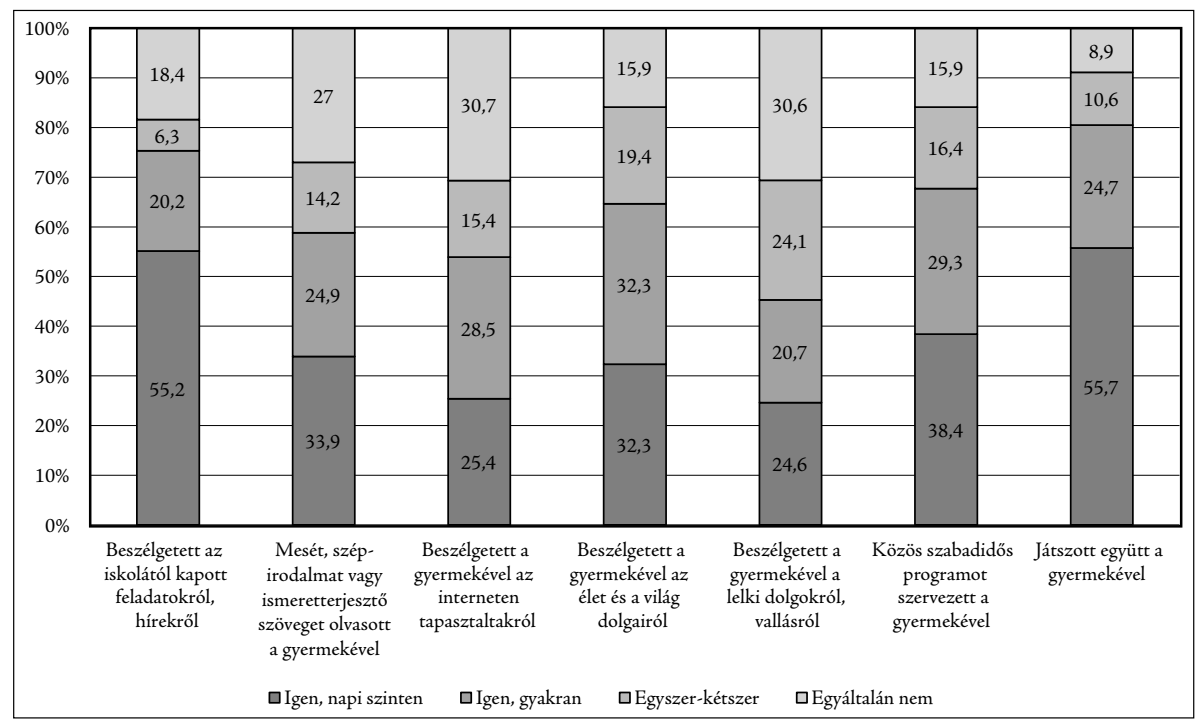

4. ábra: A digitális oktatásra történő átállást követően milyen gyakran fordult elő,

hogy Ön... (N = 259). Forrás: A koronavírus családokra gyakorolt hatásának kutatása

A gyermekre való időráfordítás vizsgálatához használt itemeket a 4. ábrán szemléltetjük. A szülők több mint fele napi szinten beszélgetett gyermekével az iskolától kapott feladatokról és játszott gyermekével. A szülők többsége gyakran értekezett a gyermekkel az élet és a világ dolgairól, illetve közös szabadidős programot is szerveztek velük. A legkevésbé gyakorinak azok a beszélgetések bizonyultak, melyek az interneten tapasztaltakra, illetve a gyermek lelki dolgaira, vallásosságára vonatkoztak. Az „Értékteremto gyermeknevelés" kutatás során is vizsgáltuk a táblázatban felsorolt tevékenységek gyakoriságát. A két vizsgálat eredményeit csak nagyon óvatosan szabad összehasonlítani, ám mégis kirajzolódnak bizonyos tendenciák. Így például arra következtethetünk, hogy a járványhelyzet során nőtt a napi szintű mese, szépirodalom olvasására fordított idő, többet beszélgettek az interneten tapasztaltakról és a gyermek lelki, vallási dolgairól, több közös szabadidős programot szerveztek és a gyermekkel való közös játék ideje is nőtt. A z eredményekből arra következtethetünk tehát, hogy a karantén alatt a szülők több és minőségibb időt tudtak gyermekeikkel tölteni.

Elemzésünk későbbi részében a gyermekre való időráfordítás vizsgálathoz a 4. ábrán feltüntetett változókból egy indexet hoztunk létre, ahol 0-ra kódoltuk az egyáltalán nem vagy egyszer-kétszer gyakorisági mutatót, míg 1-re kódoltuk a gyakran és a napi szintü gyakoriságot. Így egy hétfokú skálát hoztunk létre, ahol a skálaátlag 2,36.

A gyermekre fordított időn túl vizsgáltuk azt is, hogy egyes tevékenységeket (5.ábra) gyakrabban végeztek-e a családok közösen a karantén alatt. A felsorolt tevékenységeket a szülők csaknem fele gyakrabban végezte. Legnagyobb arányban az étkezést és a házimunkát végezték sürübben együtt, míg legkevésbé a közös sportolást. 


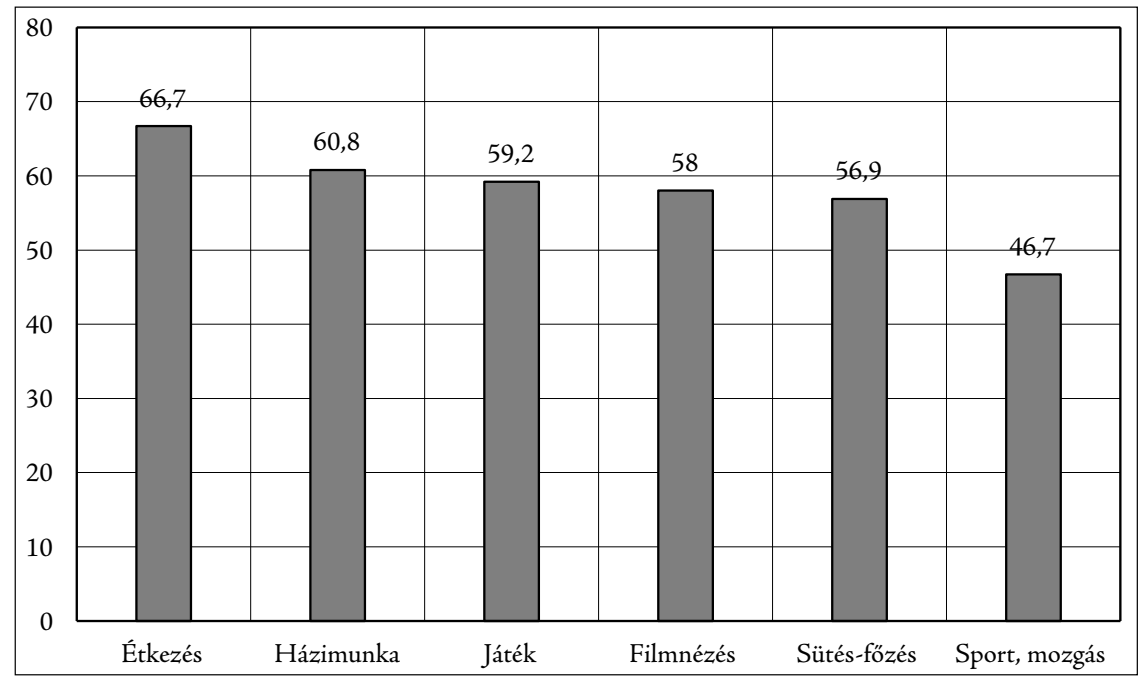

5. ábra: Az alábbi tevékenységek közül melyiket végzik most gyakrabban közösen? $(N=259)$ Forrás: A koronavírus családokra gyakorolt hatásának kutatása

A közösen végzett tevékenységekből szintén létrehoztunk egy családi időtöltést mutató indexváltozót, ahol a $0=$ nem végezte, 1 = végezte. Így egy $0-6$-ig terjedő skálát kaptunk, melynek átlaga 3,48.

\section{Közös tanulás, különböző otthonok}

A következőkben kereszttábla- és varianciaelemzéssel vizsgáljuk, hogy a bemutatott változók milyen összefüggést mutatnak azzal, hogy gyakrabban tanult-e a szülő a gyermekével a járványhelyzet alatt (1. táblázat). Fontos felhívni a figyelmet arra, hogy az együtt tanulást mérő változónk nem képes árnyaltan megmutatni azt, hogy a közös tanulás mennyisége és minősége pontosan mit takar. Így például azt, hogy a feladatok elvégzésének kontrolljára vonatkozik-e vagy a feladatokat, tananyagot közösen értelmező jellegü tevékenységet jelent.

Az édesanyák és az édesapák hasonló arányban tanulnak együtt gyermekeikkel. A település típusa nem mutatott szignifikáns eltéréseket, néhány százalékos különbséggel nagyobb arányban tanultak gyermekeikkel a községben, faluban élők, mint a nagyobb településen lakók. Az iskolai végzettség tekintetében sem szignifikánsak a különbségek, a számok azt jelzik, hogy az alacsonyabb végzettséggel rendelkezők (nyolc általános vagy kevesebb, szakmunkásképző) kissé nagyobb arányban tanultak együtt gyermekükkel, mint a magasabb végzettségűek. A család anyagi helyzetét vizsgáló index sem mutatott szignifikáns kapcsolatot a függő változóval, az átlagok összevetéséből azt sejthetjük, hogy a jobb anyagi helyzettel rendelkezők valamivel kevesebbet tanultak gyermekükkel az online tanulás alatt. Összességében azt láthatjuk, hogy a társadalmi háttértényezők nem mutattak szignifikáns összefüggést a vizsgált változóval, így első hipotézisünk nem igazolódott be ezen a mintán. Óvatosan fogalmazva azt mondhatjuk, hogy vészhelyzet idején olyannyira összezárnak a családok, hogy a szocioökonómiai státusjellemzők mentén elhalványulnak vagy eltünnek a klasszikus különbségek. 
1. táblázat: A vizsgált változók $(N=259)$

\begin{tabular}{|c|c|c|c|}
\hline Változók & Attribútumok & $\begin{array}{l}\text { Gyakrabban } \\
\text { tanul }\end{array}$ & Szignifikancia \\
\hline \multirow[t]{2}{*}{ Nem } & férfi & 54,20 & \multirow{2}{*}{0,466} \\
\hline & nő & 58,80 & \\
\hline \multirow[t]{4}{*}{ Településtípus } & fôváros & 48,80 & \multirow{4}{*}{0,068} \\
\hline & megyeszékhely & 52,00 & \\
\hline & egyéb város & 51,40 & \\
\hline & község, falu & 68,20 & \\
\hline \multirow[t]{5}{*}{ Iskolai végzettség } & nyolc általános vagy kevesebb & 65,60 & \multirow{5}{*}{0,493} \\
\hline & szakmunkásképző, szakiskola & 63,60 & \\
\hline & szakközépiskolai, gimnáziumi érettségi & 55,20 & \\
\hline & $\begin{array}{l}\text { középiskola utáni nem felsőfokú } \\
\text { végzettség (technikum, OKJ stb.) }\end{array}$ & 60,00 & \\
\hline & $\begin{array}{l}\text { föiskolai, egyetemi diploma, tu- } \\
\text { dományos fokozat }\end{array}$ & 50,60 & \\
\hline \multirow{2}{*}{$\begin{array}{l}\text { Anyagi helyzet index } \\
\text { (átlag) }\end{array}$} & gyakrabban tanul & 1,57 & \multirow{2}{*}{0,610} \\
\hline & nem tanul gyakrabban & 1,63 & \\
\hline \multirow[t]{6}{*}{ Munkavégzés } & teljes munkaidő & 56,80 & \multirow{2}{*}{0,984} \\
\hline & nem teljes munkaidőben & 56,90 & \\
\hline & részmunkaidő & 59,10 & \multirow{2}{*}{0,825} \\
\hline & nem részmunkaidőben & 56,70 & \\
\hline & távmunka & 37,50 & \multirow{2}{*}{0,044} \\
\hline & nem távmunkában & 58,90 & \\
\hline \multirow[t]{5}{*}{ Gyermekszám } & egy & 44,30 & \multirow{5}{*}{0,034} \\
\hline & kettő & 64,40 & \\
\hline & három & 53,80 & \\
\hline & négy & 76,90 & \\
\hline & több & 70,00 & \\
\hline \multirow{2}{*}{$\begin{array}{l}\text { Gyermekre való idő- } \\
\text { ráfordítás index (átlag) }\end{array}$} & gyakrabban tanul & 2,72 & \multirow{2}{*}{0,003} \\
\hline & nem tanul gyakrabban & 1,96 & \\
\hline \multirow{2}{*}{$\begin{array}{l}\text { Családi időtöltés } \\
\text { index (átlag) }\end{array}$} & gyakrabban tanul & 4,08 & \multirow{2}{*}{0,000} \\
\hline & nem tanul gyakrabban & 2,68 & \\
\hline
\end{tabular}

Forrás: A koronavírus családokra gyakorolt hatásának kutatása

A közös tanulással összefüggésben a távmunka kapcsán szignifikáns az összefüggés. Ennek értelmében a távmunkában dolgozók 37,5\%-a és a nem távmunkában dolgozók $58,3 \%$-a vallotta úgy, hogy gyakrabban tanult gyermekével. Az eredményekből úgy tünhet, hogy az otthoni munkavégzés nem segíti a gyermekkel közös tanulást, feltételezhetően inkább elvonja az időt tőle. 
A gyermekszám is szignifikáns kapcsolatot mutatott az otthoni közös tanulással, a gyermekszámmal ugyanis növekszik a ráfordított idő mennyisége. Éles választóvonal ebben a negyedik gyermek, mivel a négy- vagy többgyermekes családok esetén jellemzőbb, hogy nagyobb arányban tanulnak együtt a gyermekkel.

A gyermekkel és a családdal töltött több idő pozitív összefüggést mutat a közös tanulással. Azok a szülők, akik a digitális oktatásra történő átállást követően több időt fordítottak a gyermekeikre (pl. többet beszélgettek, játszottak velük), szignifikánsan gyakrabban is ültek le tanulni velük. Hasonló eredményekre utal a családdal közösen töltött idő is, hiszen ahol gyakrabban végeztek együtt egyes tevékenységeket a karantén alatt, azok a szülők a gyermekkel is gyakrabban tanultak közösen. A kereszttáblaés varianciaelemzések (összefoglaló táblázat) tehát igazolták második hipotézisünket, miszerint a családok közös időtöltése (gyermekkel, család többi tagjával) pozitívan hat az együtt tanulásra.

A kereszttábla elemzésen túl többlépcsős logisztikus regresszió segítségével is megvizsgáltuk, hogy a koronavírus okozta első karanténidőszak elején mi befolyásolta, hogy a válaszadó szülők közül ki tanult többet a gyermekével (2. táblázat). Ehhez bevontuk a korábban vizsgált változók közül a nemet, a településtípust és a válaszadó legmagasabb iskolai végzettégét mint a legfontosabb demográfiai háttértényezőket. Második lépcsőben az anyagi helyzetet mérő indexet és hogy a válaszadó távmunkában dolgozott-e a lekérdezés idején. A harmadik lépcsőben fontosnak tartottuk bevonni a gyermekszámot is. Végül a negyedik lépcsőben két indexet vontunk be az elemzésbe: az egyiket a gyermekkel való törődés kérdésblokkjából hoztuk létre, a másikban a családdal való közös időtöltésre vonatkozó kérdéseket egyesítettük.

Ahogyan a 2. táblázatban is látható, a szociodemográfiai változóknak és a gyermekszámnak sem volt szignifikáns hatása az elemzés egyik lépésében sem a gyermekkel való együtt tanulásra, bár a kereszttábla elemzések a magasabb gyermekszám és a távmunka negatív összefüggését jelezték elöre. A regresszióelemzésünkben a szignifikáns hatást

2. táblázat: Logisztikus regressziós elemzés $(N=259)$

\begin{tabular}{|c|c|c|c|c|}
\hline Magyarázó változók & $\begin{array}{l}\text { 1. lépcső } \\
\exp (B)\end{array}$ & $\begin{array}{l}\text { 2. lépcső } \\
\exp (B)\end{array}$ & $\begin{array}{c}\text { 3. lépcső } \\
\exp (B)\end{array}$ & $\begin{array}{l}\text { 4. lépcső } \\
\exp (B)\end{array}$ \\
\hline $\operatorname{Nem}(1=$ férfi $)$ & 0,816 & 0,818 & 0,812 & 1,209 \\
\hline Településtípus ( 1 = föváros, megyeszékhely) & 0,736 & 0,733 & 0,792 & 0,925 \\
\hline Iskolázottság ( 1 = diplomás $)$ & 0,741 & 0,821 & 0,817 & 0,649 \\
\hline Anyagi helyzet index & - & 0,990 & 1,006 & 0,996 \\
\hline Távmunkában dolgozik-e ( 1 = igen $)$ & - & 0,475 & 0,478 & 0,497 \\
\hline Gyermekszám & - & - & 1,267 & 1,267 \\
\hline Gyermekkel való törődés index & - & - & - & $1,255^{\star *}$ \\
\hline Közös időtöltés a családdal index & - & - & - & $1,497^{* * *}$ \\
\hline Nagerleke $R^{2}$ & 0,021 & 0,035 & 0,052 & 0,248 \\
\hline$R_{L}^{2}$ & 0,011 & 0,019 & 0,029 & 0,175 \\
\hline
\end{tabular}

${ }^{*} p<0,05 ;{ }^{* *} p<0,01 ;{ }^{* * *} p<0,001$

Forrás: A koronavírus családokra gyakorolt hatásának kutatása 
az utolsó vizsgálati szakaszban tudtunk kimutatni: eszerint azok, akik a karantén ideje alatt a gyermekeikkel többet törődtek (többet játszanak velük, többször olvasnak nekik stb.), azok a tanulást tekintve is többet foglalkoztak a gyermekükkel. A másik szignifikáns összefüggés pedig arról árulkodik, hogy azok, akik a családjukkal több közös tevékenységet üznek (ez akár háztartási munka is lehet, de filmnézés, sportolás is), azok másfélszer nagyobb eséllyel segítenek a gyermeknek a tanulásban is.

\section{Összegzés}

Elemzésünkben a 2020. áprilisi, koronavírus-járvány miatt bevezetett karantént követően felvett, nemre, településtípusra, iskolai végzettségre reprezentatív országos kérdőíves felmérés adatbázisát használtuk fel. A Kopp Mária Intézet felkérésére készített, A koronavirus családokra gyakorolt hatása nevet kapó kutatás lekérdezése telefonon keresztül zajlott. Az 1000 fő válaszadóból azokra szükítettük le a kutatást, akiknek kiskorú gyermeke van. A vírusszabályok betartására, a meghozott rendelkezések értékelésére vonatkozó kérdéssorból tanulmányunkban az otthontanulásra, a gyermekekkel való időtöltésre vonatkozó kérdéseket emeltük ki, s ezeket elemeztük.

Első hipotézisünkben feltételeztük, hogy a szülők iskolai végzettsége befolyásolja a tanulókkal való otthoni tanulást, mégpedig az iskolázottság csökkenésével mérséklödik az együtt tanulás. Ez a feltételezés nem igazolódott, hiszen a szülők kvalifikáltsága nem befolyásolta a közös tanulás gyakoriságát. Sőt, további társadalmi csoportjellemzők (település típusa, anyagi helyzet) sem mutattak szignifikáns összefüggést. Mindebből azt a következtetést vonhatjuk le, hogy ebben a speciális helyzetben minden szülö igyekszik a legtöbbet megtenni gyermeke tanulásának elősegítésében. A kérdőív alapján a közös tanulás gyakoriságát látjuk, eredményességét nem. Így az erőfeszítések tanulási teljesítményben megmutatkozó hatásáról, pontos mennyiségi és minőségi jellegéről nincs információnk.

A közös tanulás mennyiségi mutatóit a szülő munkavégzése és a gyermekek száma befolyásolja érdemben. Amennyiben a szülő otthonról dolgozik, kevesebb ideje jut gyermeke iskolai feladatának ellenőrzésére, segítésére. A gyermekszám növekedése viszont mindinkább bevonja a szülőt ebbe a tevékenységbe, ez különösen a négy vagy több gyermeket nevelőknél figyelhető meg.

Eredményeinkből az derült ki, hogy a vírus okozta iskolabezárás első hullámában az otthoni tanulást leginkább a család minőségi együtt töltött ideje határozta meg. Minél több programot szerveznek közösen a szülők a gyermekeikkel, minél több időt töltenek akár egyszerűnek tűnő tevékenységekkel (házimunka, étkezés) vagy tudatos odafigyeléssel (meseolvasás, játék), annál hatékonyabb a tanulásra való odafigyelés. A családi kapcsolatok erőssége másfélszeresével növeli a szülői időráfordítást az otthoni tanulásban.

Összességében úgy tűnik tehát, hogy a társadalmi státust meghatározó anyagi, kulturális tőke nagyságát felülírja a családon belüli kapcsolati tőke mozgósítása. Ezt a következtetést megfelelő óvatossággal vonjuk le, hiszen a felmérés különleges helyzetben készült, amikor - más, itt nem elemzett kérdések alapján egyértelmü, hogy - a családtagok egymás egészségéért nagyobb mértékben aggódnak, jobban odafigyelnek egymásra, a megszokottnál is szorosabbra vonják kapcsolataikat bezárt otthonaikban. Másrészt a nevelt gyermekek különböző életkori csoportokba tartoznak, ennek megfelelöen 
különböző mértékű segítséget igényelnek a tananyag feldolgozásában (ahogyan normál körülmények között is).

Eredményeink értelmezése során fontos a kutatás korlátairól is szót ejtenünk. Az egyik legfontosabb limitáció az adatfelvétel idejéből fakad: a kérdezetteket a korlátozások viszonylag korai szakaszában kerestük fel. A járvány okozta bizonytalanság már akkor is magas volt, viszont az intézkedések elfogadottsága, betartása is jellemző volt a társadalomra, míg a bezártságba, az izolációba, a korlátozásokba való belefásultság még nem jelent meg nagymértékben. Szintén a kutatáshoz kapcsolódó limitáció az adatfelvétel módszere, azaz a telefonos lekérdezés torzító hatásai, így például nem biztos, hogy mindenki fel tudta venni a telefont - talán éppen munka miatt. Újból hangsúlyozzuk azt is, hogy a teljes mintán belüli kis elemszámú almintát elemeztük, hiszen az otthontanulásról szóló blokkra csak a gyermeket nevelő szülők válaszoltak.

Ahogyan az iskolákat, úgy a szülőket is váratlanul érték az új intézkedések. Ezért limitációt jelent az is, hogy egyrészről a mindennapi nehézségeket még nem feltétlenül tudták megfogalmazni a szülők, másrészt a társadalmi státusszal magyarázható különbségek sem biztos, hogy kirajzolódhattak ilyen rövid idő alatt. A járvány által legsúlyosabban érintett ágazatokban dolgozó szülők sem feltétlenül érezték még ekkor a vírus okozta recesszió hatását, az emberek többsége befelé, a családja felé fordult.

A következő fontos limitációnk, hogy az eredetei lekérdezés célja bővebb volt, nem kizárólag az otthoni tanulás szülői megélésére vonatkozott, ezt a mintavétel is jól mutatja. Ha az otthontanulást szeretnénk a későbbiekben bővebben vizsgálni, akkor érdemes a kiskorú gyermekeket nevelő szülői populációra fókuszálni, illetve az otthontanulásra vonatkozó kérdéseket bővíteni. Továbbá meg kell említenünk, hogy az otthoni tanulás eredményességét semmilyen módon nem mérte a vizsgálat: nem tudjuk tehát, hogy a különböző hátterű szülők segítségnyújtása milyen fokú eredményességre vezetett a tanulók tanulmányi előrehaladásában. Ezért célszerű lenne kidolgozni egy mérőeszközt, ami az otthontanulás pontos mennyiségi és minőségi jellegének vizsgálatára is alkalmas.

Mindezeket figyelembe véve szükséges megtervezni a kutatás folytatását, amennyiben lehetőség adódik egy újabb adatfelvételre.

\section{IRODALOM}

Bencéné, F. A. (2020) Digitális oktatás a család szemszögéből. In: Engler Á., Rébay M. \& То́тн D. A. (eds) Család a nevelés és az oktatás fókuszában. ONK absztraktkötet. Debrecen, MTA-DE-KINCS. p. 322.

Bloemen, H. G. \& Stancanelli, E. G. F. (2008) How Do Parents Allocate Time? The Effects of Wages and Income. IZA Discussion Papers No. 3679. Bonn, Institute for the Study of Labor (IZA).

Boudon, R. (1974) Education, Opportunity and Social Inequality. New York, Wiley.

Boudon, R. (1998) Társadalmi egyenlőtlenségek a továbbtanulásban. In: Halász G. \&

Lannert J. (ed.) Oktatási rendszerek elmélete. Budapest, Okker Kiadó. pp. 406-417.

Bourdieu, P. (1978) A társadalmi egyenlötlenségek újratermelödése. Budapest, Gondolat.

Brown, S. (2006) Family Structure Transitions and Adolescent Well-Being. Demography,

Vol. 43. No. 3. pp. 447-461.

Buda B. (1998) Empátia... a beleélés lélektana. Budapest, Ego School. 
Coleman, J. S. (1988) Social Capital in the Creation of the Human Capital. American Journal of Sociology, Vol. 94. pp. 95-120.

Connelly, R. \& Kimmel, J. (2007) Spousal Influences on Parents' Non-market Time Choices. IZA Discussion Papers No. 2894. Bonn, Institute for the Study of Labor (IZA).

Ceglédi T. (2018) Ugródeszkán. Debrecen, CHERD.

Coleman, J. S. (1974) Iskolai teljesítmény és versenystruktúra. In: Ferge Zs. - Háber J. (eds) Az iskola szociológiai problémái. Budapest, Közgazdasági és Jogi Könyvkiadó. pp. 377-397.

Craig, L., Powell, A. \& Smyth, C. (2014) Towards Intensive Parenting? Changes in the Composition and Determinants of Mothers' and Fathers' Time with Children 19922006. The British Journal of Sociology, Vol. 65. No 3. pp. 555-579. DOI: 10.1111/14684446.12035

Croll, P. (2004) Families, Social Capital and Educational Outcomes. British Journal of Educational Studies, Vol. 52. No. 4. pp. 390-416.

Dimaggio, P. J. (1998) A kulturális tőke és az iskolai teljesítmény: A struktúrákban való részvétel hatása az egyesült államokbeli középiskolások jegyeire. In: RóBERT P. (ed.) Társadalmi mobilitás. Hagyományos és új megközelitések. Budapest, Új Mandátum Könyvkiadó. pp. 198-220.

Di Pietro, G., Biagi, F., Costa, P., Karpiński, Z. \& Mazza, J. (2020) The Likely Impact of COVID-19 on Education: Reflections Based on the Existing Literature and Recent International Datasets. Luxembourg, Publications Office of the European Union.

Dusa Á. R. (2020) Gyermeknevelési értékek. Kapocs, Vol. 3. No. 2. pp. 21-31.

Engler Á. (2011) Kisgyermekes nők a felsőoktatásban. Budapest, Gondolat.

Epstein, J. L., Galindo, C. L. \& Sheldon, S. B. (2011) Levels of Leadership. Effects of District and School Leaders on the Quality of School Programs of Family and Community Involvement. Educational Administration Quarterly, Vol. 47. No. 3. pp. 462 495.

Gauthier, A., Smeeding, T. M. \& Furstenberg Jr., F. F. (2004) Are Parents Investing Less Time in Children? Trends in Selected Industrialized Countries. Population And Development Review. Vol. 30. No. 4. pp. 647-671.

Harcsa I. (2014) Családi kohézió - A szülök és a gyermekek társas együttléte a mindennapok világában. A gyermekes családokban élök idöfelhasználása. Budapest, Központi Statisztikai Hivatal.

ImRe N. (2015) A szülői részvétel formái és hatása a tanulói eredményességre. In: Arató F. (ed.) Horizontok II. A pedagógusképzés reformjának folytatása. Pécs, Pécsi Tudományegyetem. pp. 127-141.

Kalenkoski, C., Ribar, D. C. \& Stratton, L. S. (2008) The Influence of Wages on Parents' Time Allocation of Time to Child Care and Market Work in the United Kingdom. Journal of Population Economics, Vol. 22. No. 2. pp. 399-419. DOI: 10.1007/ s00148-008-0192-9

Kelley, D. \& Sequeira, D. L. (1997) Understanding Family Functioning in a Changing America. Communication Studies, Vol. 48. No. 2. pp. 93-108.

Kéri K. (2020) Múlt a jövőben: neveléstörténet a digitális korban. Civil Szemle, Különszám 2020, pp. 23-37.

Kopp M. \& Skrabski Á. (2000) Pszichoszociális tényezők és egészségi állapot. Demográfia, Vol. 43. Nos 2-3. pp. 252-258.

Kozma T. (1999) Bevezetés a nevelésszociológiába. Budapest, Nemzeti Tankönyvkiadó. 
Markos V. (2020) A tanórán kívüli foglalkozásokon való részvétel és a társadalmi háttér összefüggései. Kapocs, Vol. 3. No. 2. pp. 43-51.

Minály I H. (2020) A járvány hatása az emberekre - gyenge és erős kötések szerepe a járvány elviselésében. Szellem és Tudomány, 2020/2. pp. 47-86.

Molnár Gy. (2020) Kutatás-fejlesztés és innováció az oktatásban: A „Szegedi Mühely” informatikai fejlesztései és gyakorlati alkalmazásuk. Civil Szemle, Különszám 2020, 93-105.

Oostdam, R. \& Hooge, E. (2013) Making the Difference with Active Parenting: Forming Educational Partnerships between Parents and Schools. European Journal of Psychology of Education, Vol. 28. No. 2. pp. 337-351.

Osvátr A. \& PApp Z. A. (2020) Digitális fordulat az oktatásban? A digitális távoktatás tapasztalatai, lehetséges következményei. Szellem és Tudomány, 2020/2. pp. 179-204.

Papp-Danka A. (2014) Az online tanulási környezettel támogatott oktatási formák tanulásmódszertanának vizsgálata. Budapest, ELTE Eötvös Kiadó.

Proнácziк Á. (2020) A tantermi és az on-line oktatás (tanítás és tanulás) összehasonlító elemzése. Opus et Educatio, Vol. 7. No. 3. pp. 208-219.

Pusztai G. (2005) Társadalmi háttér és iskolai pályafutás. Educatio, Vol. 14. No. 3. pp. 534-553.

Pusztai G. (2020) A vallásosság nevelésszociológiája - Kutatások vallásos nevelésröl és egyházi oktatásról. Budapest, Gondolat.

Pusztai G. \& Engler Á. (2020) Értékteremtő gyermeknevelés a családban és az oktatásban. Kapocs, Vol. 3. No. 2. pp. 3-11.

Róвект P. (2001) Társadalmi mobilitás. Tények és vélemények tükrében. Budapest, Andorka Rudolf Társadalomtudományi Társaság - Századvég Kiadó.

RóBERT P. (2004) Iskolai teljesítmény és társadalmi háttér nemzetközi összehasonlításban. In: Kolosi T., Tóth I. Gy. \& Vukovich Gy. (eds) Társadalmi Riport 2004. Budapest, TÁRKI. pp. 193-205.

Serfőző M., Golyán Sz., F. Lassú Zs., Svraka B. \& Aggné P. V. (2020) Digitalizáció és online tanulás a pedagógusképzésben - hallgatói visszajelzések a távolléti oktatásról. Civil Szemle, Különszám 2020. pp. 105-117.

Shahzad, A., Hassan, R. \& Aremu, A. Y. (2020) Effects of COVID-19 in E-learning on Higher Education Institution Students: The Group Comparison between Male and Female. Quality and Quantity. https://doi.org/10.1007/s11135-020-01028-z

Sheldon, S. \& Epstein, J. (2005) Involvement Counts: Family and Community Partnerships and Mathematics Achievement. The Journal of Educational Research, Vol. 98. No. 4. pp. 196-206.

Shivangi, D. (2020) Online Learning: A Panacea in the Time of COVID-19 Crisis. Journal of Educational Technology Systems, Vol. 49. No. 1. pp. 5-22.

Siraj-Blatchford, I. (2010) Learning in the Home and at School: How Working Class Children 'Succeed Against the Odds'. British Educational Research Journal, Vol. 36. No. 3. pp. 463-482.

Szemerszki M. (2015) Tanulói eredményesség dimenziói és háttértényezői. In: Szemerszki M. (ed.) Eredményesség az oktatásban. Budapest, OFI. pp. 52-88.

SzưTs Z. (2020) A tanárképzés digitális transzformációjának kevésbé exponált elemei $(\mathrm{Az}$ intézmény, a szülő, és a tanár új szerepei). Civil Szemle, Különszám 2020. pp. 133-145. 
ThéKes I. (2020) COVID-19 vírusjárvány miatti hazai távoktatás digitális megoldásainak elemzése. In: Kozma G. (ed.) Fejezetek a COVID-19-es távoktatás digitális tapasztalataiból. Szeged, Gerhardus Kiadó. pp. 7-17.

TürkoğLu, B. \& Uslu, M. (2019) The Opinions of University Graduate Working Mothers Who Have 36-60-Months-Old Children about the Quality of the Time Spent with Their Children. A Phenomenological Analysis. International Journal of Progressive Education, Vol. 15. No. 3. pp. 123-143. DOI: 10.29329/ijpe.2019.193.9

Vandeleur, C. L., Jeanpretre, N., Perrez, M., Schoebi, D. \& Mcbride Murry, V. (2009) Cohesion, Satisfaction with Family Bonds, and Emotional Well-Being in Families With Adolescents. Journal of Marriage and Family Volume, Vol. 71. No. 5. pp. 12051219.

Volling, B. L., Notaro, P. C. \& Larsen, J. J. (1998) Relations with Emotional Wellbeing, Marriage, and Parenting. Family Relations The Family as a Context for Health and Well-being. Vol. 47. No. 4. pp. 355-367.

Zick, C. D., Bryant, W. K. \& Österbacka, E. (2001) Mothers' Employment, Parental Involvement, and the Implication for Intermediate Child Outcomes. Social Science Research, Vol. 30. No 1. pp. 25-49. DOI: http://dx.doi.org/10.1006/ssre.2000.0685

A cikk a Creative Commons Attribution 4.0 International License (https://creativecommons,org/licenses/ by/4.0/) feltételei szerint publikált Open Access közlemény, melynek szellemében a cikk bármilyen médiumban szabadon felhasználható, megosztható és újraközölhető, feltéve, hogy az eredeti szerző és a közlés helye, illetve a CC License linkje és az esetlegesen végrehajtott módosítások feltüntetésre kerülnek. (SID_1) 